\title{
KESALAHAN PENGGUNAAN EJAAN \\ DALAM KARANGAN EKSPOSISI SISWA KELAS X MIPA 1 SMA NEGERI 3 KOTA JAMBI
}

\author{
Uli Wahyuni ${ }^{1}$, Mira Munita Sari ${ }^{2}$ \\ Program Studi Pendidikan Bahasa dan Sastra Indonesia \\ Fakultas Keguruan dan Ilmu Pendidikan, Universitas Batanghari, \\ Jambi \\ uli09yumna@gmail.com \\ miramunitasari@gmail.com
}

\begin{abstract}
This purpose of this research is to describe the errors of spelling in expository composition of class X MIPA 1 at SMA negeri 3 Kota Jambi academic year 2018/2019. This research used qualitative descriptive method. The data of this research was sequence of sentences of students' writing with spelling errors. The primary data was students' expository composition of class X MIPA 1 at SMA Negeri 3 Kota Jambi Tahun academic year 2018/2019. Based on the result of the analysis, it can be found that the errors of spelling in expository composition of students' class X MIPA 1 semeter I SMA negeri 3 kota Jambi tahun ajaran 2018/2019 were 713 errors. The errors of spelling consists of 588 errors of using capital letter in the beginning of the sentence; 4 errors of using capital letter in the beginning of the sentence with direct quote; 10 errors of using capital letter as the first letter of nation name; 2 errors of using capital letter as the first letter of days' name; 3 errors of capital letter as the first letter of geography; 14 errors of capital letter of every word in the title of their composition. Moreover, there following errors of the use of comma is; 60 errors of comma in between of elements of explanation; 4 errors of comma before conjunction; 11 errors of comma behind the conjunction of sentences; 7 errors of comma in separating direct quote from the other parts of the sentence; 2 errors of comma in between of district or country's name which is written in sequence; 9 errors of comma on the back of the information of the beginning of the sentence which is used to avoid error of reading.
\end{abstract}

Keywords: Spelling, Essay Exposition

\footnotetext{
${ }^{1}$ Dosen Program Studi Pendidikan Bahasa dan Sastra Indonesia, Fakultas Keguruan dan Ilmu Pendidikan, Universitas Batanghari, Jambi

${ }^{2}$ Mahasiswa Program Studi Pendidikan Bahasa dan Sastra Indonesia, Fakultas Keguruan dan Ilmu Pendidikan, Universitas Batanghari, Jambi

Kesalahan Penggunaan Ejaan dalam Karangan Eksposisi Siswa Kelas X MIPA 1 SMA Negeri 3 Kota Jambi
} 


\section{PENDAHULUAN}

Bahasa Indonesia dijadikan salah satu mata pelajaran pokok di sekolah. Mata pelajaran ini bertujuan untuk mengajarkan berbagai ranah keilmuan berbahasa dan juga keterampilan berbahasa. Menurut Setia, Erlina Zahar, Ade Rahim (2018:184) pembelajaran bahasa Indonesia di sekolah bertujuan untuk mengasah kemampuan intelektual, serta kematangan emosional, dan sosial siswa.

Salah satu keterampilan berbahasa yang diajarkan di sekolah khususnya di SMA adalah keterampilan menulis eksposisi. Menurut Gustaviana dan Rahima (2018:187) Keterampilan menulis merupakan keterampilan yang kompleks karena memerlukan pemahaman terhadap kaidah tatatulis. Salah satu kaidah tata tulis yang perlu diperlu dipahami siswa sebelum menulis adalah kaidah Ejaan. Kesalahan penggunaan Ejaan Bahasa Indonesia dalam karangan siswa masih banyak ditemukan. Oleh karena itu, kajian tentang kesalahan penggunaan bahasa khususnya ejaan masih pelu dilakukan.

Analisis kesalahan merupakan suatu pengkajian untuk mengetahui kesalahan-kesalahan pada pemakaian bahasa dalam berbahasa dan mencoba mencari tahu hal-hal apa saja yang menimbulkan kesalahan tersebut sampai dengan cara bagaimanakah kesalahan itu dapat diperbaiki. Kesalahan menurut Dulay (dalam Tarigan, 1988:142), "Adalah bagian-bagian konversasi atau komposisi yang menyimpang dari norma baku (norma terpilih) dari performansi bahasa orang dewasa".

Analisis kesalahan adalah suatu kegiatan mengamati, menganalisis, mengklasifikasi, dan mengungkapkan sesuatu dari sistem yang beroperasi dalam diri pembelajar, mengundang kemunculan kajian tentang kesalahn pembelajar (Rofii, 2014). Analisis kesalahan berbahasa sangat diperlukan dalam pelajaran yang diajarkan di sekolah terutama dalam menulis karangan. Karena dengan analisis kesalahan berbahasa para guru dapat mengatasi kesulitan yang ada pada siswa agar tidak terjadi lagi kesalahan dalam berbahasa. Salah satu aspek kesalahan berbahasa yaitu ejaan.

Ejaan merupakan suatu unsur penting di dalam bahasa. Ejaan adalah aturan atau pedoman menulis, serta penggambaran lambang-lambang bunyi ujaran. Aturan-aturan dalam ejaan terdiri atas: pemakaian huruf, penulisan kata, pemakaian tanda baca, dan penulisan unsur serapan. Ejaan sangatlah penting dalam kehidupan sehari-hari, khususnya dalam hal tulis menulis. Jika salah menggunakan ejaan, maka pembaca dapat salah dalam pemahaman sehingga tidak mengerti maksud dari tulisan yang disampaikan.

Arifin dan Tasai (2009:164), mengemukakan bahwa, "Ejaan adalah keseluruhan peraturan bagaimana melambangkan bunyi ujaran dan bagaimana antarhubungan antara lambang-lambang itu (pemisahan dan penggabungannya dalam suatu bahasa)“. Ini berarti ejaan sangatlah penting dalam dunia tulis-menulis. Dengan ejaanlah bunyi-bunyi berupa kata, kalimat dapat tersampaikan dengan jelas maknanya.

Menurut Azwardi (2018:15) fungsi ejaan antara lain: “(1) Landasan pembakuan tata bahasa; 2) landasan pembakuan kosakata dan peristilahan dan, 3) alat penyaring masuknya unsurunsur bahasa lain ke dalam bahasa Indonesia". Selanjutnya menurut Mustakim (1996:3) di samping ketiga fungsi yang telah disebutkan di atas, ejaan sebenarnya juga mempunyai fungsi yang lain: "Secara praktis, ejaan berfungsi untuk membantu pemahaman

Kesalahan Penggunaan Ejaan dalam Karangan Eksposisi Siswa Kelas X MIPA 1 SMA Negeri 3 
pembaca di dalam mencerna informasi yang disampaikan secara tertulis. Dalam hal ini fungsi praktis itu dapat dicapai jika segala ketentuan yang terdapat di dalam kaidah telah diterapkan dengan baik".

Berdasarkan fungsi ejaan di atas, dapat disimpulkan fungsi ejaan sebagai pedoman dalam menulis dan menyajikan karya tulis sehingga makna dari tulisan tersebut dapat tersampaikan dengan jelas dan tidak salah dalam menafsirkannya. Fungsi ejaan ini yang digunakan untuk menganalisis kesalahan penggunaan ejaan yang terdapat di dalam karangan eksposisi.

Karangan adalah hasil rangkaian kegiatan seseorang dalam mengungkapkan gagasan atau buah pikirannya melalui bahasa tulis yang dapat dibaca dan dimengerti oleh orang lain yang membacanya. Finoza, (2008:234) menyatakan bahwa, "Karangan adalah hasil penjabaran suatu gagasan secara resmi dan teratur tentang suatu topik atau pokok bahasan."

Karangan eksposisi adalah karangan yang memuat suatu persoalan tentang topik tertentu dan memiliki pernyataan yang menunjukkan sikap penulis dalam menanggapi suatu persoalan tersebut. Alwasilah dan Alwasilah, (2008:111), "Eksposisi adalah tulisan yang tujuan utamanya mengklarifikasi, mendidik, atau mengevaluasi sebuah persoalan. Sejalan dengan pendapat diatas menurut Suherli, dkk. (2016:53) menyatakan bahwa, "Eksposisi biasa digunakan seseorang untuk menyajikan gagasan. Gagasan tersebut dikaji oleh penulis atau pembicara berdasarkan sudut pandang tertentu. Untuk menguatkan gagasan yang disampaikan, penulis atau pembicara harus menyertakan alasanalasan logis".

"Writing skill is one of four language skills that must be mastered by students (Keterampilan menulis merupakan salah satu dari empat keterampilan berbahasa yang harus dikuasai oleh siswa Rofii dkk. (2019). Keterampilan menulis secara baik dan benar merupakan modal penting bagi seorang siswa, dalam mengerjakan tugas sekolah. Siswa yang mampu menulis secara baik dan benar serta mengikuti kaidah bahasa Indonesia akan lebih mudah dalam mengerjakan tugas.

Berdasarkan pengamatan yang telah dilaksnakan di SMA Negeri 3 Kota Jambi kelas X MIPA 1 ternyata masih banyak ditemukan kesalahan penggunaan ejaan dalam karangan. Misalnya, siswa masih kebingungan kapan suatu huruf harus ditulis dengan huruf kapital, kapan suatu tanda baca, seperti koma (,) digunakan.

Berdasarkan latar belakang yang telah dikemukakan, maka fokus penelitian ini adalah kesalahan penggunaan huruf yang mengacu pada huruf kapital, dan kesalahan penggunaan tanda baca yang mengacu pada tanda baca koma. Adapun pertanyaan penelitian ini,

1. Bagaimanakah kesalahan penggunaan huruf kapital dalam karangan eksposisi siswa kelas X MIPA 1 SMA Negeri 3 Kota Jambi tahun ajaran 2018/2019?

2. Bagaimanakah kesalahan penggunaan tanda baca koma dalam karangan eksposisi siswa kelas $\mathrm{X}$ MIPA 1 Semester I SMA Negeri 3 Kota Jambi tahun ajaran 2018/2019?

Berdasarkan latar belakang masalah di atas, penelitian ini bertujuan untuk:

1. mendeskripsikan bentuk kesalahan penggunaan huruf kapital dalam karangan eksposisi siswa kelas $\mathrm{X}$ MIPA 1 SMA Negeri 3 Kota Jambi tahun ajaran 2018/2019.

2. mendeskripsikan bentuk kesalahan penggunaan tanda baca koma dalam karangan eksposisi siswa kelas $\mathrm{X}$

Kesalahan Penggunaan Ejaan dalam Karangan Eksposisi Siswa Kelas X MIPA 1 SMA Negeri 3 
MIPA 1 SMA Negeri 3 Kota Jambi tahun ajaran 2018/2019.

\section{METODE PENELITIAN}

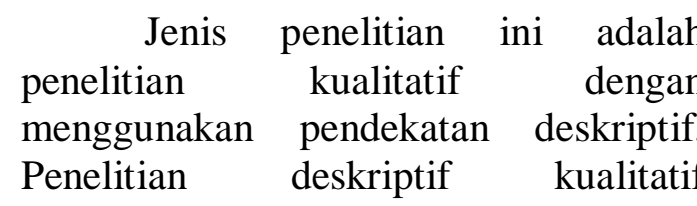
merupakan metode yang digunakan untuk meneliti objek untuk mendapatkan tujuan pemahaman. Menurut Zaim (2014:14) dalam penelitian bahasa, "Deskriptif yaitu data yang dikumpulkan adalah gejala bahasa berupa kata-kata, bukan angka-angka". Sejalan dengan pendapat di atas Lincoln dan Guba (dalam Moleong 2012:11) mengatakan bahwa ciri-ciri penelitian kualitatif itu bersifat deskriptif yaitu "Data yang dikumpulkan adalah berupa kata-kata, gambar, dan bukan angka-angka.

Data dalam penelitian ini adalah serangkaian kata-kata yang teridentifikasi terdapat kesalahan ejaan dalam karangan eksposisi siswa kelas $X$ MIPA 1 SMA Negeri 3 Kota Jambi tahun ajaran 2018/2019.

Sumber data utama dalam penelitian ini adalah karangan eksposisi siswa kelas X MIPA 1 semester I SMA Negeri 3 Kota Jambi tahun ajaran 2018/2019.

Teknik pengumpulan data dalam penelitian ini dilakukan dengan langkahlangkah sebagai berikut.

1. Dokumen-dokumen didapatkan sewaktu peneliti melaksanakan praktek pengalaman lapangan (PPL) di SMA Negeri 3 Kota Jambi tahun ajaran 2018/2019.

2. Setelah hasil karangan siswa didapatkan, peneliti membaca satu persatu karangan siswa secara keseluruhan dengan cermat, teliti, dan berulang kali.

3. Peneliti menandai kata-kata yang teridentifikasi terdapat kesalahan ejaan yang mengacu pada huruf ejaan yang mengacu pada huruf penggunaan tanda baca koma ditemukan
Kesalahan Penggunaan Ejaan dalam Karangan Eksposisi Siswa Kelas X MIPA 1 SMA Negeri 3 Kota Jambi kapital, dan kesalahan tanda baca koma.

4. Selanjutnya, temuan kesalahan yang telah di dapat, dimasukkan ke dalam tabel tabulasi.

Teknik analisis data dalam penelitian ini, menggunakan teknik analisis isi yang dikemukakan Miles dan Huberman (dalam Sugiyono, 2018:132) bahwa aktivitas dalam analisis data, yaitu data reduction, data display, dan conclusion drawing/verification.

Berikut langkah-langkah teknik analisis data dalam penelitian ini.

1. Peneliti merangkum dan mengklasifikasikan data-data sesuai dengan fokus penelitian.

2. Setelah data-data diklasifikasikan, lalu dimasukkan ke dalam tabel, dan diberi uraian singkat.

3. Merumuskan kesimpulan

\section{HASIL DAN PEMBAHASAN}

Berdasarkan hasil analisis data yang telah dilakukan, ditemukan 713 kesalahan penggunaan ejaan dalam karangan eksposisi siswa kelas X MIPA 1 semester I SMA Negeri 3 Kota Jambi tahun ajaran 2018/2019. Kesalahan penggunaan huruf kapital ditemukan pada: (1) penggunaan huruf kapital sebagai huruf pertama awal kalimat, ditemukan sebanyak 588 kesalahan; (2) huruf kapital pada awal kalimat dalam petikan langsung, ditemukan sebanyak 4 kesalahan; (3) huruf kapital sebagai huruf pertama nama bangsa, suku bangsa, dan bahasa, ditemukan sebanyak 10 kesalahan; (4) huruf kapital sebagai huruf pertama nama hari, ditemukan sebanyak 2 kesalahan; (5) huruf kapital sebagai huruf pertama nama geografi, ditemukan sebanyak 4 kesalahan; (6) huruf kapital sebagai huruf pertama setiap kata di dalam judul karangan, ditemukan sebanyak 14 kesalahan.

Selanjutnya, kesalahan penggunaan tanda baca koma ditemukan
posisi Siswa Kelas X MIPA 1 SMA Negeri 3 
pada: (1) tanda koma digunakan di antara unsur-unsur dalam suatu pemerincian, ditemukan sebanyak 60 kesalahan; (2) tanda koma digunakan di belakang kata atau ungkapan penghubung antarkalimat, ditemukan sebanyak 11 kesalahan; (3) tanda koma digunakan di belakang keterangan yang terdapat pada awal kalimat untuk menghindari salah baca, ditemukan sebanyak 9 kesalahan; (4) tanda koma digunakan untuk memisahkan petikan langsung dari bagian lain dalam kalimat, ditemukan sebanyak 7 kesalahan; (5) tanda koma digunakan di antara nama wilayah, ditemukan sebanyak 7 kesalahan; (6) tanda koma digunakan sebelum kata penghubung, ditemukan sebanyak 4 kesalahan

\section{Kesalahan Penggunaan Huruf Kapital}

a. Huruf Kapital sebagai Huruf Pertama Awal Kalimat dalam Karangan Eksposisi Siswa Kelas X MIPA 1 SMA Negeri 3 Kota Jambi

Kutipan (AA.1)

"Kelapa adalah buah dengan 1000 Manfaat bagi Manusia."

Pada kutipan kalimat siswa (AA.1) penggunaan huruf $M$ pada kata Manfaat dan Manusia tersebut salah, karena bertentangan dengan aturan penggunaan huruf kapital. Sesuai pendapat Waridah (2016:5), huruf kapital digunakan sebagai huruf pertama di awal kalimat, sedangkan huruf $M$ terdapat di tengah kalimat. Berikut perbaikan kutipan kalimat siswa (AA.1)

"Kelapa adalah buah dengan 1000 manfaat bagi manusia"

b. Huruf Kapital sebagai Huruf Pertama Unsur Nama Orang dalam Karangan Eksposisi Siswa Kelas X MIPA 1 SMA Negeri 3 Kota Jambi

Kesalahan Penggunaan Ejaan dalam Karangan Eksposisi Siswa Kelas X MIPA 1 SMA Negeri 3
Penggunaan huruf kapital sebagai huruf pertama unsur nama orang tidak ditemukan dalam karangan eksposisi siswa.

c. Huruf Kapital sebagai Huruf Pertama pada Awal Kalimat dalam Petikan Langsung dalam Karangan Eksposisi Siswa Kelas X MIPA 1 SMA Negeri 3 Kota Jambi

Kutipan (BP.1)

"Ekonomi rakyat adalah bagian"kegiatan ekonomi rakyat banyak."

Pada kutipan kalimat siswa (BP.1) penggunaan huruf $k$ pada kata kegiatan, tersebut salah, karena bertentangan dengan aturan penggunaan huruf kapital. Sesuai pendapat Waridah (2016:6), huruf kapital digunakan pada awal kalimat dalam petikan langsung. Berikut perbaikan kutipan kalimat siswa (BP.1)

"Ekonomi rakyat adalah bagian "Kegiatan ekonomi rakyat banyak."

d. Huruf Kapital sebagai Huruf Pertama Nama Agama, Kitab Suci, dan Tuhan dalam Karangan Eksposisi Siswa Kelas X MIPA 1 SMA Negeri 3 Kota Jambi

Penggunaan huruf kapital sebagai huruf pertama nama agama, kitab suci, dan tuhan tidak ditemukan dalam karangan eksposisi siswa.

e. Huruf Kapital sebagai Huruf Pertama Unsur Nama Gelar Kehormatan, Keturunan, Keagamaan, atau Akademik yang diikuti Nama Orang, termasuk Gelar Akademik yang Mengikuti Nama Orang dalam Karangan Eksposisi Siswa Kelas X MIPA 1 SMA Negeri 3 Kota Jambi

Penggunaan huruf kapital sebagai huruf pertama unsur nama gelar kehormatan, keturunan, keagamaan, atau 
akademik yang diikuti nama orang, termasuk gelar akademik yang mengikuti nama orang tidak ditemukan dalam karangan siswa.

f. Huruf Kapital sebagai Huruf Pertama Unsur Nama Jabatan dan Pangkat yang diikuti Nama Orang sebagai Pengganti Nama Orang Tertentu, Nama Instansi, atau Nama Tempat dalam Karangan Eksposisi Siswa Kelas X MIPA 1 SMA Negeri 3 Kota Jambi

Penggunaan huruf kapital sebagai huruf pertama unsur nama jabatan dan pangkat yang diikuti nama orang sebagai pengganti nama orang tertentu, nama instansi, atau nama tempat tidak ditemukan dalam karangan siswa.

g. Huruf Kapital sebagai Huruf Pertama Nama Bangsa, Suku Bangsa, dan Bahasa. dalam Karangan Eksposisi Siswa Kelas X MIPA 1 SMA Negeri 3 Kota Jambi

Kutipan (HF.1)

"Batik adalah salah satu kain dan hasil kebudayaan yang asli indonesia."

Pada kutipan kalimat siswa (HF.1) penggunaan huruf $i$ pada kata indonesia tersebut salah, karena bertentangan dengan aturan penggunaan huruf kapital. Sesuai pendapat Waridah (2016:8), huruf kapital digunakan sebagai huruf pertama nama bangsa. Berikut perbaikan kutipan kalimat siswa (HF.1)

"Batik adalah salah satu kain dan hasil kebudayaan yang asli Indonesia”.

h. Huruf Kapital sebagai Huruf Pertama Nama Hari dalam Karangan Eksposisi Siswa Kelas X MIPA 1 SMA Negeri 3 Kota Jambi
"Banyak manfaat yg di peroleh dari kegiatan jumat bersih..."

\section{Pada kutipan kalimat siswa} (PY.7) penggunaan huruf $j$ pada kata jumat, tersebut salah, karena bertentangan dengan aturan penggunaan huruf kapital. Sesuai teori Waridah (2016:8), huruf kapital digunakan sebagai huruf pertama nama hari. Berikut perbaikan kutipan siswa (PY.7)

"Banyak manfaat yang di peroleh dari kegiatan Jumat bersih..."

i. Huruf Kapital sebagai Huruf Pertama Nama Geografi dalam Karangan Eksposisi Siswa Kelas X MIPA 1 SMA Negeri 3 Kota Jambi

Kutipan (ZA.5)

"Kue kelepon berasal dari Krian Sidoarjo jawa Timur."

Pada kutipan kalimat siswa (ZA.5) penggunaan huruf $j$ pada kata jawa tersebut salah, karena bertentangan dengan aturan penggunaan huruf kapital. Sesuai teori Waridah (2016:9), huruf kapital digunakan sebagai huruf pertama nama geografi. Berikut perbaikan kutipan kalimat siswa (ZA.5)

"Kue kelepon berasal dari Krian Sidoarjo Jawa Timur."

j. Huruf Kapital sebagai Huruf Pertama Semua Kata dalam Nama Negara, Lembaga, Badan, Organisasi, atau Dokumen dalam Karangan Eksposisi Siswa Kelas X MIPA 1 SMA Negeri 3 Kota Jambi

Penggunaan huruf kapital sebagai huruf pertama semua kata dalam nama negara, lembaga, badan organisasi atau dokumen tidak ditemukan dalam karangan eksposisi siswa.

Kutipan (PY.7)

Kesalahan Penggunaan Ejaan dalam Karangan Eksposisi Siswa Kelas X MIPA 1 SMA Negeri 3 
k. Huruf Kapital sebagai Huruf Pertama Setiap Kata di dalam Judul Buku, Karangan, Artikel, dan Majalah Kecuali Kata Tugas dalam Karangan Eksposisi Siswa Kelas X MIPA 1 SMA Negeri 3 Kota Jambi

Kutipan (DM.1)

"olahraga untuk kesehatan Tubuh"

Pada kutipan kalimat siswa (FS.1) penggunaan huruf $o$ pada kata olahraga, penggunaan huruf $k$ pada kata kesehatan adalah salah, karena bertentangan dengan aturan penggunaan huruf kapital. Sesuai teori Waridah (2016:11), huruf kapital digunakan sebagai huruf pertama setiap kata pada judul karangan, kecuali kata tugas. Berikut perbaikan kutipan kalimat siswa (FS.1)

\section{"Olahraga untuk Kesehatan Tubuh."}

1. Huruf Kapital sebagai Huruf Pertama Unsur Singkatan Nama Gelar, Pangkat, atau Sapaan dalam Karangan Eksposisi Siswa Kelas X MIPA 1 SMA Negeri 3 Kota Jambi

Kesalahan penggunaan huruf kapital sebagai huruf pertama unsur singkatan nama gelar, pangkat, atau sapaan tidak ditemukan dalam karangan eksposisi siswa.

m. Huruf Kapital sebagai Huruf Pertama Kata Petunjuk Kekerabatan dalam Karangan Eksposisi Siswa Kelas X MIPA 1 SMA Negeri 3 Kota Jambi

Kesalahan penggunaan huruf kapital sebagai huruf pertama kata petunjuk kekerabatan tidak ditemukan dalam karangan eksposisi siswa.

\section{Kesalahan Penggunaan Tanda Baca Koma (,)}

a. Koma digunakan di antara Unsurunsur dalam Suatu Pemerincian atau Pembilang dalam Karangan Eksposisi Siswa Kelas X MIPA 1 SMA Negeri 3 Kota Jambi

Kutipan (AA.1)

"Air kelapa Memiliki kandungan: mineral protein karbohidrat dan vit. C."

Pada kutipan kalimat siswa (AA.1) pada kata mineral protein karbohidrat dan vit. $C$ tersebut salah, karena bertentangan dengan aturan penggunaan tanda baca koma. Sesuai teori Waridah (2016:34), tanda koma digunakan di antara unsur-unsur dalam suatu pemerincian atau pembilangan. Berikut perbaikan kutipan kalimat siswa (AA.1)

"Air kelapa Memiliki kandungan: mineral protein karbohidrat dan vit. C."

b. Tanda Koma digunakan sebelum Kata Penghubung, dalam kalimat Majemuk Setara dalam Karangan Eksposisi Siswa Kelas X MIPA 1 SMA Negeri 3 Kota Jambi

Kutipan (GT.1)

"Dari hal itu, dapat dibayangkan betapa besar kerusakan alam yang terjadi karena jumlah populasi yang besar, konsumsi sumber daya alam dan populasi yang meningkat sedangkan, teknologi saat ini belum dapat menyelesaikan permasalahan tersebut."

Pada kutipan kalimat siswa (GT.1) pada kata meningkatkan tersebut salah, karena bertentangan dengan aturan penggunaan tanda baca koma. Sesuai teori Waridah (2016:34), tanda koma digunakan sebelum kata penghubung seperti sedangkan, dalam kalimat majemuk setara. Berikut perbaikan kutipan kalimat siswa (GT.1)

"Dari hal itu, dapat dibayangkan betapa besar kerusakan alam yang terjadi karena jumlah populasi yang besar,

Kesalahan Penggunaan Ejaan dalam Karangan Eksposisi Siswa Kelas X MIPA 1 SMA Negeri 3 
konsumsi sumber daya alam dan populasi yang meningkat, sedangkan teknologi saat ini belum dapat menyelesaikan permasalahan tersebut."

c. Tanda Koma digunakan untuk Memisahkan Anak Kalimat yang Mendahului Induk Kalimat dalam Karangan Eksposisi Siswa Kelas X MIPA 1 SMA Negeri 3 Kota Jambi

Kesalahan penggunaan tanda koma untuk memisahkan anak kalimat yang mendahului induk kalimat tidak ditemukan dalam karangan eksposisi siswa.

d. Tanda Koma digunakan di Belakang Kata atau Ungkapan Penghubung antarkalimat dalam Karangan Eksposisi Siswa Kelas X MIPA 1 SMA Negeri 3 Kota Jambi

Kutipan (DW.1)

"Namun hal tersebut tidak menyadarkan mereka agar membuang sampah pada tempatnya, dan tidak membuang sampah sembarangan."

Pada kutipan kalimat siswa (DW.1) pada kata namun tersebut salah, karena bertentangan dengan aturan penggunaan huruf kapital. Sesuai teori Waridah (2016:34), tanda koma digunakan di belakang kata atau ungkapan penghubung antarakalimat. Berikut perbaikan kutipan kalimat siswa (DW.1)

"Namun, hal tersebut tidak menyadarkan mereka agar membuang sampah pada tempatnya, dan tidak membuang sampah sembarangan."

e. Tanda Koma digunakan sebelum dan atau sesudah Kata Seru dalam Karangan Eksposisi Siswa Kelas X MIPA 1 SMA Negeri 3 Kota Jambi

Kesalahan penggunaan tanda koma sebelum dan atau sesudah kata seru tidak ditemukan di dalam karangan eksposisi siswa.

f. Tanda Koma digunakan untuk Memisahkan Petikan Langsung dari Bagian Lain dalam Kalimat dalam Karangan Eksposisi Siswa Kelas X MIPA 1 SMA Negeri 3 Kota Jambi

Kutipan (BP.2)

"Perspektif lain dari nama ekonomi rakyat ini dapat dilihat juga dengan menggunakan perspektif jargon "Ekonomi untuk rakyat, dari rakyat, dan oleh rakyat."

Pada kutipan kalimat siswa (BP.2) pada kata jargon tersebut salah, karena bertentangan dengan aturan penggunaan tanda baca koma. Sesuai teori Waridah (2016:35), tanda koma digunakan untuk memisahkan petikan langsung dari bagian lain dalam kalimat. Berikut perbaikan kutipan kalimat siswa (BP.2)

"Perspektif lain dari nama ekonomi rakyat ini dapat dilihat juga dengan menggunakan perspektif jargon, "Ekonomi untuk rakyat, dari rakyat, dan oleh rakyat."

g. Tanda Koma digunakan di antara Nama Tempat dan Wilayah atau Negeri yang ditulis Berurutan. dalam Karangan Eksposisi Siswa Kelas X MIPA 1 SMA Negeri 3 Kota Jambi

Kutipan (ZA.1)

"Kue kelepon berasal dari Krian Sidoarjo Jawa Timur."

Pada kutipan kalimat siswa (ZA.1) pada kata Krian Sidoarjo dari kutipan S.1 tersebut salah, karena bertentangan dengan aturan penggunaan tanda baca koma. Sesuai teori Waridah (2016:35), tanda koma digunakan di antara nama tempat dan wilayah atau negeri yang ditulis berurutan. Berikut perbaikan kutipan kalimat siswa (ZA.1)

Kesalahan Penggunaan Ejaan dalam Karangan Eksposisi Siswa Kelas X MIPA 1 SMA Negeri 3 
"Kue kelepon berasal dari Krian, Sidoarjo, Jawa Timur."

h. Tanda Koma digunakan untuk Memisahkan Bagian Nama yang dibalik Susunannya dalam Daftar Pustaka dalam Karangan Eksposisi Siswa Kelas X MIPA 1 SMA Negeri 3 Kota Jambi

Kesalahan penggunaan tanda koma untuk memisahkan bagian nama yang dibalik susunannya dalam daftar pustaka tidak ditemukan dalam karangan eksposisi siswa.

i. Tanda Koma digunakan di antara Bagian-bagian dalam Catatan Kaki dalam Karangan Eksposisi Siswa Kelas X MIPA 1 SMA Negeri 3 Kota Jambi

Kesalahan penggunaan tanda koma di antara bagian-bagian dalam catatan kaki tidak ditemukan dalam karangan eksposisi siswa.

j. Tanda Koma digunakan di antara Nama Orang dan Singkatan Gelar Akademis dalam Karangan Eksposisi Siswa Kelas X MIPA 1 SMA Negeri 3 Kota Jambi

Kesalahan penggunaan tanda koma di antara nama orang dan singkatan gelar akademis tidak ditemukan dalam karangan eksposisi siswa.

k. Tanda Koma digunakan sebelum Angka Desimal atau di antara Rupiah dan Sen yang dinyatakan dengan Angka dalam Karangan Eksposisi Siswa Kelas X MIPA 1 SMA Negeri 3 Kota Jambi

Kesalahan penggunaan tanda koma sebelum angka desimal atau di antara rupiah dan sen yang dinyatakan dengan angka tidak ditemukan dalam karangan siswa.

1. Tanda Koma digunakan untuk Mengapit Keterangan Tambahan atau
Keterangan Aposisi dalam Karangan Eksposisi Siswa Kelas X MIPA 1 SMA Negeri 3 Kota Jambi

Kesalahan penggunaan tanda koma untuk mengapit keterangan tambahan atau keterangan aposisi tidak ditemukan dalam karangan eksposisi siswa.

m. Tanda Koma digunakan di Belakang Keterangan yang Terdapat pada Awal Kalimat untuk Menghindari Salah Baca/Salah Pengertian dalam Karangan Eksposisi Siswa Kelas X MIPA 1 SMA Negeri 3 Kota Jambi

Kutipan (LA.3)

"Setelah musim kemarau air kembali menguap dan kembali menjadi awan."

Pada kutipan kalimat siswa (LA.3) pada kata kemarau tersebut salah, karena bertentangan dengan aturan penggunaan tanda koma. Sesuai teori Waridah (2016:37), tanda koma digunakan di belakang keterangan yang terdapat pada awal kalimat untuk menghindari salah baca/salah pengertian.. Berikut perbaikan kutipan kalimat siswa (LA.3)

"Setelah musim kemarau, air kembali menguap dan kembali menjadi awan."

\section{SIMPULAN}

Berdasarkan hasil penelitian dan pembahasan dapat disimpulkan bahwa terdapat beberapa kesalahan penggunaan ejaan dalam menulis karangan eksposisi siswa kelas X MIPA 1 semester I SMA Negeri 3 Kota Jambi tahun ajaran 2018/2019. Berdasarkan hasil penelitian dari 30 karangan eksposisi siswa, diketahui bahwa terdapat 713 kesalahan penggunaan huruf kapital dan kesalahan penggunaan tanda baca koma sebagai berikut.

1. Ditemukan kesalahan penggunaan huruf kapital sebanyak 620

Kesalahan Penggunaan Ejaan dalam Karangan Eksposisi Siswa Kelas X MIPA 1 SMA Negeri 3 
kesalahan, yang terdiri dari: (1) kesalahan penggunaan huruf kapital sebagai huruf pertama awal kalimat sebanyak 588 kesalahan; (2) kesalahan penggunaaan huruf kapital sebagai huruf pertama setiap kata di dalam judul buku sebanyak 14 kesalahan; (3) kesalahan penggunaan huruf kapital sebagai huruf pertama nama bangsa sebanyak 10 kesalahan;

kesalahan penggunaan huruf kapital sebagai huruf pertama pada awal kalimat dalam petikan langsung sebanyak 4 kesalahan; (5) kesalahan penggunaan huruf kapital sebagai huruf pertama nama geografi sebanyak 2 kesalahan; (6) kesalahan penggunaan huruf kapital sebagai huruf pertama nama hari sebanyak 2 kesalahan; dan 7 penggunaan huruf kapital lainnya tidak ditemukan.

2. Ditemukan kesalahan penggunaan tanda baca koma sebanyak 93 kesalahan, yang terdiri atas: (1) kesalahan penggunaan tanda koma di antara unsur-unsur dalam suatu pemerincian sebanyak 60 kesalahan; (2) kesalahan penggunaan tanda koma di belakang kata atau ungkapan penghubung antarkalimat sebanyak 11 kesalahan; kesalahan penggunaan tanda koma untuk menghindari salah baca/salah pengertian sebanyak 9 kesalahan; (4) kesalahan penggunaan tanda koma untuk memisahkan petikan langsung dari bagian lain dalam kalimat sebanyak 7 kesalahan; (5) kesalahan penggunaan tanda koma sebelum kata penghubung seperti tetapi, sedangkan dalam kalimat majemuk setara sebayak 4 kesalahan; (6) kesalahan penggunaan tanda koma untuk nama tempat dan wilayah atau negeri yang ditulis berurutan sebanyak 2 kesalahan, dan (7) penggunaan tanda baca koma lainnya tidak ditemukan.

\section{Saran}

Beberapa saran terkait dengan hasil penelitian ini sebagai berikut.

1. Bagi siswa, harus banyak membaca buku Pedoman Umum Ejaan Bahasa Indonesia (PUEBI) dan memahaminya, agar mampu menulis secara baik dan benar, dan bagi siswa yang hasil kesalahannya sedikit mampu menjadi motivasi bagi siswa lain.

2. Bagi Guru, perlu meningkatkan intensitas pengajaran pada aspek ejaan, dengan cara sering memberikan latihan menulis sesuai dengan kaidah bahasa Indonesia. Penjelasan tentang kaidah ejaan dalam bahasa Indonesia juga perlu dikemas dalam suasana belajar yang menyenangkan, sehingga siswa merasa tertarik.

3. Bagi para pembaca khususnya mahasiswa Program Studi Pendidikan Bahasa dan Sastra Indonesia, agar dapat mempergunakan hasil penelitian ini sebagai masukan untuk meningkatkan wawasan tentang bahasa.

4. Bagi peneliti lain, hasil penelitian ini diharapkan dapat menjadi acuan sebagai kajian yang sama dengan fokus permasalahan yang berbeda dan bervariasi.

DAFTAR PUSTAKA

Alwasilah, A. Chaedar dan Alwasilah Senny Suzanna. (2008). Pokoknya Menulis: Cara Baru Menulis dengan Metode Kolaborasi. Bandung: Kiblat Buku Utama.

Arifin, Zaenal dan Amran Tasai. (2009). Cermat Berbahasa Indonesia untuk Perguruan Tinggi. Jakarta: Akademi Pressindo.

Kesalahan Penggunaan Ejaan dalam Karangan Eksposisi Siswa Kelas X MIPA 1 SMA Negeri 3 
Azwardi. (2018). Menulis Ilmiah. Banda Aceh: Bina Karya Akademika.

Finoza, Lamuddin. (2008). Komposisi Bahasa Indonesia. (Untuk Mahasiswa Non Jurusan Bahasa) Jakarta: Diksi.

Gustaviana, R., Rahima, A., \& Sujoko, S. (2018). Pengaruh Penggunaan Model Kepala Bernomor terhadap Keterampilan Menulis Teks Pidato Siswa Kelas IX G SMP Negeri 2 Kota Jambi Tahun Ajaran 2017/2018. Jurnal Ilmiah Dikdaya, 8(1), 187-194.

Mustakim. (1996). Tanya Jawab Ejaan Bahasa Indonesia untuk Umum. Jakarta: Gramedia.

Rofii, Afif. (2015). Analisis Kesalahan Berbahasa Indonesia dalam Surat Resmi pada Bidang Sintaksis Siswa Kelas VIII Mts N Lubuk Buaya Kota Padang. Jurnal Ilmiah Dikdaya Universitas Batanghari Jambi.Vol. 5, No. 1 http://dikdaya.unbari.ac.id/index. php/dikdaya/article/view/62

Rofii, Afif., Fathiaty, Murtadho., Rahmat, Aceng. (2019). Needs Analysis: A Learning Model for CTL-Based Academic Writing. Proceedings of the Eleventh Conference on Applied Linguistics (conaplin 2018) https://www.atlantispress.com/procedings/conaplin$\underline{18 / 125911424}$

Setia, R. B. J., Zahar, E., \& Rahima, A. (2018). Penggunaan Media Lagu Pop dalam Pembelajaran Menulis Cerpen Realis Siswa Kelas IX A SMP Negeri 9 Kota Jambi Tahun Pelajaran 2016/2017. Aksara: Jurnal Ilmiah Pendidikan Bahasa dan Sastra Indonesia, 2(1), 183-191.
Sugiyono. (2018). Metode Penelitian Kualitatif (untuk Penelitian yang Bersifat: Eksploratif, Enterpretif, Interaktif, dan Konstruktif). Bandung: Alfabeta.

Tarigan, Henry Guntur dan Djago Tarigan. (1988). Pengajaran Analisis Kesalahan Berbahasa. Bandung: Angkasa.

Waridah, Ernawati. (2016). Pedoman Umum Ejaan Bahasa Indonesia. Bandung: Ruang Kata.

Zaim, M. (2014). Metode Penelitian Bahasa (Pendekatan Struktural). Padang: FBS UNP Press Padang.

Kesalahan Penggunaan Ejaan dalam Karangan Eksposisi Siswa Kelas X MIPA 1 SMA Negeri 3 